Bangladesh J. Plant Taxon. 22(2): 111-118, 2015 (December)

\title{
MOLECULAR EVOLUTIONARY RELATIONSHIPS OF EUPHORBIA SCORDIFOLIA JACQ. WITHIN THE GENUS INFERRED FROM ANALYSIS OF INTERNAL TRANSCRIBED SPACER SEQUENCES
}

\author{
FAHAD M.A. AL-HEMAID, M. AJMAL ALI ${ }^{1}$, JOONGKU LEE ${ }^{2}$, SOO-YONG KIM ${ }^{3}$ \\ AND M. OLIUR RAHMAN ${ }^{4}$ \\ Department of Botany and Microbiology, College of Science, King Saud University, \\ Riyadh 11451, Saudi Arabia
}

Keywords: Euphorbia scordifolia; Euphorbiaceae; ITS; Genotyping.

\begin{abstract}
The present study explored molecular phylogenetic analysis of 28 species of Euphorbia L. for the identification and establishment of molecular evolutionary relationships of Euphorbia scordifolia Jacq. within the genus based on the internal transcribed spacers (ITS) sequences (ITS1-5.8S-ITS2) of nuclear ribosomal DNA (nrDNA). The sequence similarity search using Basic Local Alignment Search Tool (BLAST) of the ITS sequence of E. scordifolia showed the closest sequence similarity to E. supina Raf. The analysis of ITS sequence data revealed four major clades consistent with subgeneric classifications of the genus. Molecular data support placement of $E$. scordifolia in the subgenus Chamaesyce.
\end{abstract}

\section{Introduction}

The genus Euphorbia L. (Euphorbiaceae) comprising ca. 2000 species, which is one of the largest genera of the flowering plants (Frodin, 2004; Riina et al., 2013). The main molecular phylogenetic studies of Euphorbia species have addressed the overall phylogeny of the genus, with its four subgeneric clades of Rhizanthium, Esula, Euphorbia, and Chamaesyce (Steinmann and Porter, 2002; Bruyns et al., 2006; Park and Jansen, 2007; Zimmermann et al., 2010). In Saudi Arabia, the genus Euphorbia is represented by 38 species. Of them, E. scordifolia Jacq. is distributed in Cape Verde Island, Ethiopia, Somalia, Sudan, Yemen and also in western region of Saudi Arabia (Abedin et al., 2001). The morphological characters of $E$. scordifolia overlap with $E$. supina Raf. (Abedin et al., 2001).

The internal transcribed spacers (ITS) sequence of nuclear ribosomal DNA region including the 5.8S gene is the most widely used molecular marker to infer phylogenetic relationships among plant species (Baldwin et al., 1995; Ali et al., 2014). Although reliance on nrDNA ITS sequence as the sole source of phylogenetic evidence has come under criticism because of certain features of its evolution; however, it remains the most efficient locus for generating species-specific phylogenetic inferences and genotyping in most groups of plants (Ali et al., 2013, 2014, 2015). While searching for DNA sequences of E. scordifolia in GenBank as a part of a research for genotyping of unresolved taxonomic status of flowering plants of Saudi Arabia, it was found that E. scordifolia have not previously been sequenced. A perusal of taxonomic literature revealed that

\footnotetext{
${ }^{1}$ Corresponding author. Email: majmalali@rediffmail.com

${ }^{2}$ Department of Environment and Forest Resources, Chungnam National University, 99 Daehak-ro, Yuseong-gu, Daejeon 34134, South Korea.

${ }^{3}$ International Biological Material Research Center, Korea Research Institute of Bioscience and Biotechnology, Daejeon 305 806, South Korea.

${ }^{4}$ Department of Botany, University of Dhaka, Dhaka 1000, Bangladesh.
} 
the molecular evolutionary relationships of E. scordifolia distributed in Saudi Arabia is also unknown. Therefore, the present study aims at molecular genotyping of E. scordifolia based on ITS sequence of nrDNA.

\section{Materials and Methods \\ Taxon sampling:}

Leaf materials of E. scordifolia were collected from the herbarium specimens [voucher- AlRawshan, altitude $1122 \mathrm{~m}, 19.08 .1978$, Don Bermant 146] housed at National Herbaium \& Genebank, National Agriculture \& Animal Resources Research Center, Ministry of Agriculture, Riyadh, Saudi Arabia (RIY); and the taxonomic identification was confirmed through consultation of Flora of Saudi Arabia (Abedin et al., 2001).

\section{DNA extraction, amplification and sequencing:}

Total genomic DNA was extracted using Qiagen DNeasy Plant Mini Kit (Valencia, CA, USA). ITS sequences of nuclear ribosomal DNA were amplified using AccuPower HF PCR PreMix (Bioneer, Daejeon, South Korea) and primer ITS1 (5 -GTCCACTGAACCTTATCATTT AG-3 ${ }^{\prime}$ ) and ITS4 (5'-TCCTCCGCTTATTGATATGC-3') of White et al. (1990) via polymerase chain reaction (PCR). Each $20 \mu \mathrm{l}$ volumes of PCR premix contained $2 \mu \mathrm{l}$ of $10 \mathrm{x}$ buffer, $300 \mu \mathrm{M}$ dNTPs, $1 \mu \mathrm{l}$ of a $10 \mathrm{pM}$ solution of each primer and 1 unit of HF DNA polymerase. One round of amplification consisted of denaturation at $94{ }^{\circ} \mathrm{C}$ for $5 \mathrm{~min}$, followed by 40 cycles of denaturation at $94{ }^{\circ} \mathrm{C}$ for $1 \mathrm{~min}$, annealing at $49{ }^{\circ} \mathrm{C}$ for $1 \mathrm{~min}$ and extension at $72{ }^{\circ} \mathrm{C}$ for $1 \mathrm{~min}$, and a final extension for $5 \mathrm{~min}$ at $72{ }^{\circ} \mathrm{C}$. PCR products were purified with the SolGent PCR Purification KitUltra (SolGent, Daejeon, South Korea) prior to sequencing. The sequencing reaction was performed in a $10 \mu$ final volume with the BigDye Terminator cycle sequencing kit (PerkinElmer, Applied Biosystems). Cycling conditions included an initial denaturation at $94{ }^{\circ} \mathrm{C}$ for 5 min, followed by 30 cycles of $96{ }^{\circ} \mathrm{C}$ for $10 \mathrm{~s}, 50{ }^{\circ} \mathrm{C}$ for $5 \mathrm{~s}$, and $60{ }^{\circ} \mathrm{C}$ for $4 \mathrm{~min}$. The sequenced products were precipitated with $17 \mu \mathrm{l}$ of deionized sterile water, $3 \mu \mathrm{l}$ of $3 \mathrm{M} \mathrm{NaOAc}$, and $70 \mu \mathrm{l}$ of 95\% EtOH. The capillary gel electrophoresis was conducted with Long Ranger Single Packs (FMC BioProducts) by an ABI 3100 automated DNA sequencer (Perkin-Elmer, Applied Biosystems). The sequences were analyzed by ABI Sequence Navigator (Perkin-Elmer/Applied Biosystems). Nucleotide sequences of both DNA strands were analyzed to ensure accuracy. The sequences were subjected to BLAST-searched (Altschul et al., 1990) by NCBI server (http://blast.ncbi.nlm.nih.gov/Blast.cgi).

\section{Phylogenetic analysis:}

ITS sequences of nrDNA of 28 species of Euphorbia (Table 1) were retrieved from GenBank database of National Center for Biotechnology Information (www.ncbi.nlm.nih.gov). Neoguillauminia cleopatra and Dichostemma glaucescens were chosen as outgroup taxa according to previous work (Barres et al., 2011) and were retrieved from GenBank (Table 1). Sequence alignment was performed using CLUSTAL X version 1.81 (Thompson et al., 1997). Sequence alignment was subsequently adjusted manually using BioEdit (Hall, 1999). Gaps were treated as missing data in phylogenetic analyses. The generated sequences were submitted to GenBank (Table 1). The boundaries between the ITS1, 5.8S and ITS2 gene for E. scordifolia were determined in the aligned data matrix, and were exported as a Nexus file and subsequently analysed using Maximum Parsimony (MP) and Maximum Likelihood (ML) methods by MEGA5 (Tamura et al., 2011). The distribution and pattern of nucleotide substitution in all sequences was investigated using HYPERMUT (Rose and Korber, 2000). 
Table 1. Plant accessions used for the molecular phylogenetic analysis of Euphorbia scordifolia.

\begin{tabular}{|c|c|c|c|}
\hline Group & Subgenus & Taxon & $\begin{array}{l}\text { GenBank } \\
\text { Accession No. }\end{array}$ \\
\hline \multirow[t]{29}{*}{ Ingroup } & \multirow[t]{6}{*}{ Rhizanthium } & Euphorbia antso Denis & AF537579 \\
\hline & & Euphorbia atrispina N.E. Br. & AF537568 \\
\hline & & Euphorbia balsamifera Ait. & AF537571 \\
\hline & & Euphorbia clava Jacq. & AF537569 \\
\hline & & Euphorbia namuskluftensis L.C. Leach & AF537562 \\
\hline & & Euphorbia obesa Hook. f. & AF537566 \\
\hline & \multirow[t]{5}{*}{ Esula } & Euphorbia aphylla Brouss. & AF537540 \\
\hline & & Euphorbia dendroides L. & AF537539 \\
\hline & & Euphorbia peplus L. & AF537532 \\
\hline & & Euphorbia schimperi C. Presl & AF537537 \\
\hline & & Euphorbia schimperiana Hochst. ex A. Rich. & JN207816 \\
\hline & \multirow[t]{9}{*}{ Euphorbia } & Euphorbia abdelkuri Balf. f. & AF537458 \\
\hline & & Euphorbia beharensis Leandri & AJ508983 \\
\hline & & Euphorbia cylindrifolia Marn.-Lap. \& Rauh & AJ508955 \\
\hline & & Euphorbia drupifera Thonn. & AF537480 \\
\hline & & Euphorbia epiphylloides Kurz & AF537484 \\
\hline & & Euphorbia milii Des Moul. & AJ508974 \\
\hline & & Euphorbia ramipressa Croizat & AF537481 \\
\hline & & Euphorbia supina Raf. & EU659773 \\
\hline & & Euphorbia teke Schweinf. ex Pax & AF537485 \\
\hline & \multirow[t]{9}{*}{ Chamaesyce } & Euphorbia fulgens Karw. ex Klotzsch & AF537404 \\
\hline & & Euphorbia graminea Jacq. & AF537410 \\
\hline & & Euphorbia heterophylla L. & GU214931 \\
\hline & & Euphorbia ipecacuanhae L. & AF537397 \\
\hline & & Euphorbia leucocephala Lotsy & GU214932 \\
\hline & & Euphorbia misera Benth. & AF537383 \\
\hline & & Euphorbia pulcherrima Willd. ex Klotzsch & GU214943 \\
\hline & & Euphorbia scordifolia Jacq. & KR704890 \\
\hline & & Euphorbia sphaerorhiza Benth. & AF537412 \\
\hline \multirow[t]{2}{*}{ Outgroup } & & Neoguillauminia cleopatra (Baill.) Croizat & AF537581 \\
\hline & & Dichostemma glaucescens Pierre & AF537584 \\
\hline
\end{tabular}

\section{Results and Discussion}

The combined length of ITS region (ITS1-5.8S-ITS2) in E. scordifolia was $642 \mathrm{bp}$. The ITS1 region was $266 \mathrm{bp}$ (GC content 53\%), the 5.8S gene was 162 bp long (GC content 56\%), and the ITS2 region was 213 bp (GC content 58\%). The BLAST search of ITS sequence of $E$. scordifolia showed high identity level (95\%) with E. humifusa Willd. followed by $E$. glyptosperma Engelm., E. maculata L., E. tettensis Klotzsch and E. meganaesos Featherm. Parsimony analysis of the entire ITS region resulted in five maximally parsimonious trees, the consistency index was 0.491 , the retention index was 0.709 , and the composite index was 0.367 (0.348) for all sites and parsimony-informative sites (in parentheses). There were a total of 499 
positions in the final dataset, of which 223 were parsimony informative. The phylogenetic tree recovered by the analyses provided a clear resolution of taxon included in the analysis at the subgeneric level. Eupphorbia scordifolia nested within the clade of the subgenus Chamaesyce. The ML analyses recovered tree topology similar to MPT; and therefore, only the ML topology is presented here (Fig. 1). A total of 36 specific nucleotide differences, i.e. 19 in ITS1 and 17 in ITS2 region were detected between E. scordifolia and E. supina (Table 2).

Table 2. Differences of DNA base pairs between the ITS sequences of Euphorbia supina and $E$. scordifolia.

\begin{tabular}{|c|c|c|c|c|c|}
\hline \multicolumn{6}{|c|}{ Specific nucleotide differences } \\
\hline \multirow{2}{*}{$\begin{array}{l}\text { Position in } \\
\text { sequence } \\
\text { alignment }\end{array}$} & \multicolumn{2}{|c|}{ ITS1 } & \multirow{2}{*}{$\begin{array}{l}\text { Position in } \\
\text { sequence } \\
\text { alignment }\end{array}$} & \multicolumn{2}{|c|}{ ITS2 } \\
\hline & E. supina & E. scordifolia & & E. supina & E. scordifolia \\
\hline 18 & G & A & 3 & $\mathrm{~T}$ & $\mathrm{C}$ \\
\hline 41 & $\mathrm{~T}$ & $\mathrm{~T}$ & 22 & $\mathrm{C}$ & $\mathrm{T}$ \\
\hline 45 & $\mathrm{C}$ & G & 25 & $\mathrm{~T}$ & $\mathrm{C}$ \\
\hline 56 & G & $\mathrm{T}$ & 37 & - & G \\
\hline 93 & $\mathrm{C}$ & $\mathrm{T}$ & 49 & $\mathrm{C}$ & $\mathrm{T}$ \\
\hline 106 & $\mathrm{~T}$ & - & 56 & A & $\mathrm{R}$ \\
\hline 113 & $\mathrm{C}$ & $\mathrm{T}$ & 74 & $\mathrm{~T}$ & $\mathrm{C}$ \\
\hline 135 & A & $\mathrm{C}$ & 94 & $\mathrm{~T}$ & $\mathrm{C}$ \\
\hline 136 & A & $\mathrm{T}$ & 126 & $\mathrm{~T}$ & $\mathrm{C}$ \\
\hline 137 & A & $\mathrm{T}$ & 146 & A & G \\
\hline 147 & $\mathrm{~T}$ & $\mathrm{C}$ & 151 & $\mathrm{C}$ & A \\
\hline 148 & G & $\mathrm{T}$ & 163 & $\mathrm{C}$ & $\mathrm{T}$ \\
\hline 149 & $\mathrm{C}$ & $\mathrm{T}$ & 170 & $\mathrm{~T}$ & A \\
\hline 208 & $\mathrm{C}$ & $\mathrm{T}$ & 173 & G & A \\
\hline 212 & $\mathrm{C}$ & $\mathrm{T}$ & 174 & A & $\mathrm{T}$ \\
\hline 215 & $\mathrm{C}$ & $\mathrm{T}$ & 191 & $\mathrm{~T}$ & $\mathrm{C}$ \\
\hline 232 & $\mathrm{~T}$ & $\mathrm{C}$ & 192 & G & A \\
\hline 254 & G & A & & & \\
\hline 258 & G & A & & & \\
\hline
\end{tabular}

The Tandem Repeats Finder (Benson, 1999) was used to detect repeats in the ITS sequences. Differences in substitution rates can discriminate functional forms of pseudogenes (Buckler and Holtsford, 1996a,b). The analysis using the program HYPERMUT showed excessive levels of G $\Rightarrow$ A mutations which indicates that all differences arose from a single substitution sequence. The result was compared to the reference sequences and their physical locations along the sequences were graphically illustrated (Fig. 2).

The use of DNA sequences to identify organisms has been proposed as a more efficient approach than traditional and morphological taxonomic parameters (Tautz et al., 2003). In fact, the recent development in DNA molecular systematic techniques including molecular hybridization, cloning, restriction endonuclease digestions and DNA sequencing and phylogenetic theory have changed the epitome of species identification as well as our understanding of the relationships among organisms at various levels in the tree of life which has been advanced greatly 


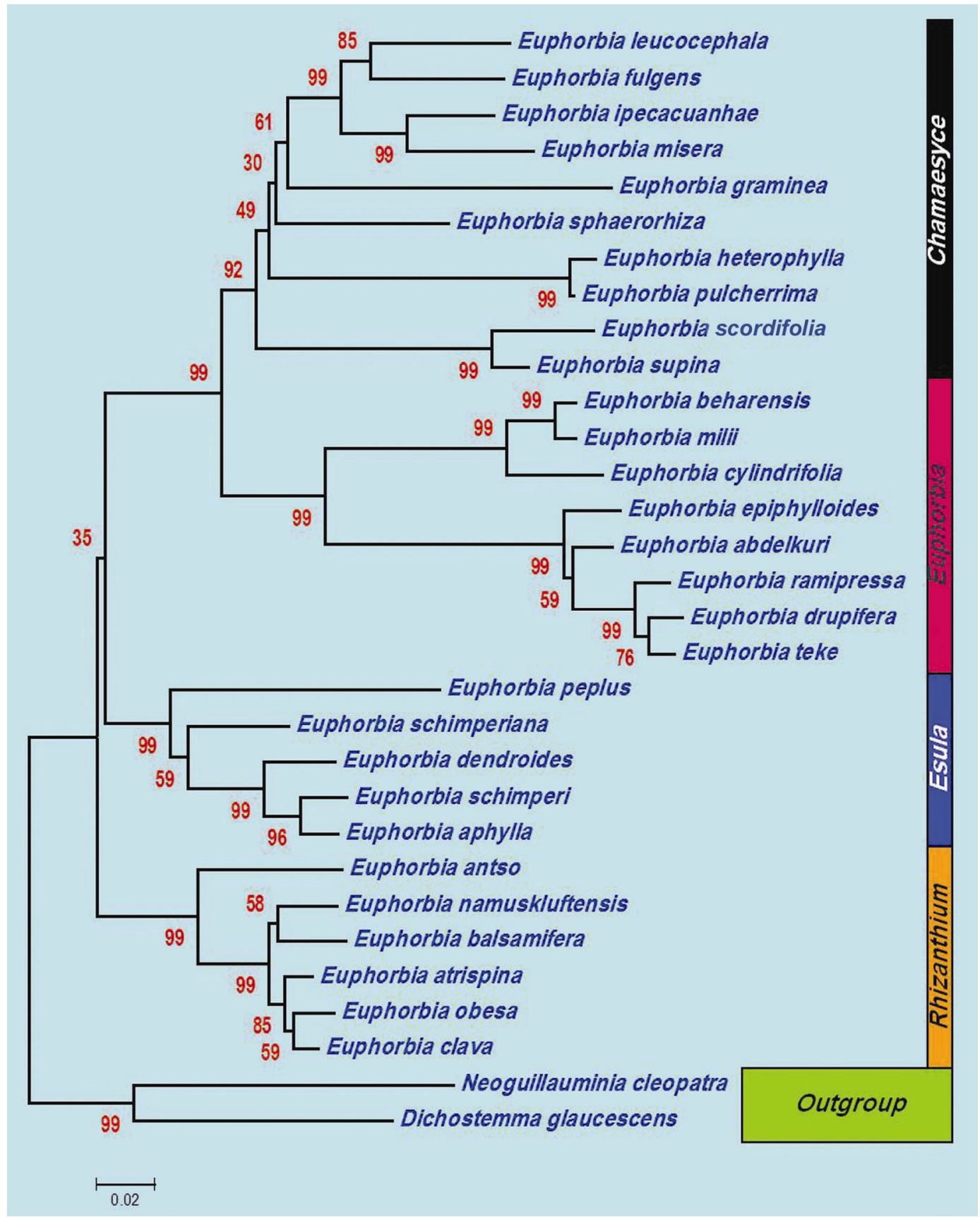

Fig.1. A maximum likelihood (ML) tree inferred from analysis of sequence data of internal transcribed spacer (ITS) region of nuclear ribosomal DNA. Bootstrap values $(1000 \times$ replicates $)$ are indicated. 


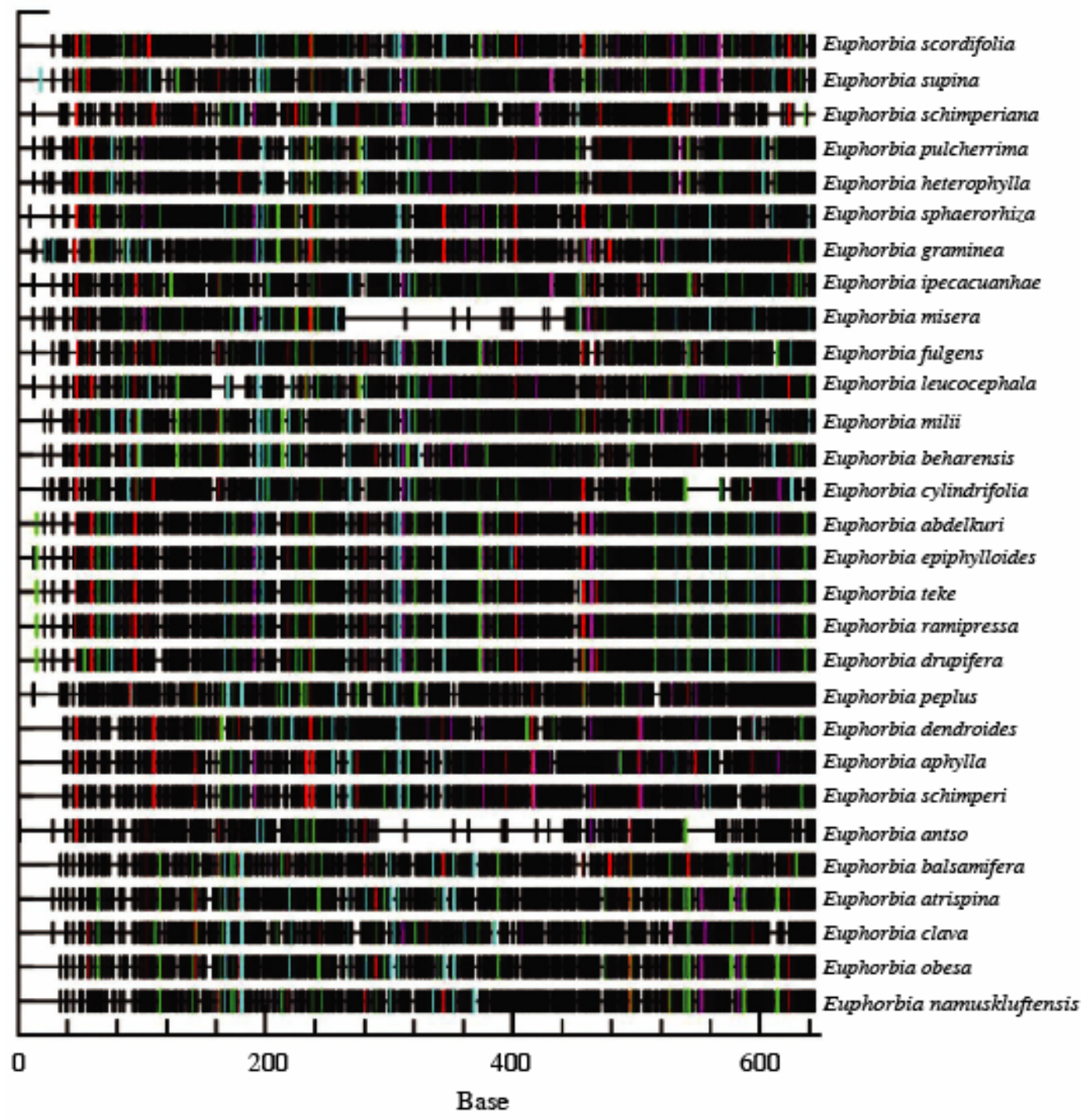

Fig. 2. Schematic illustration of the distribution of substitution sites across the ITS region obtained from 29 species of Euphorbia, using Dichostemma glaucescens as reference (red = GG > AG, cyan = GA $>$ AA, green $=\mathrm{GC}>\mathrm{AC}$, magenta $=\mathrm{GT}>\mathrm{AT}$, black $=$ not $\mathrm{G}>\mathrm{A}$ transition, yellow $=$ gap) .

(Ali et al., 2014). From the first report of the utility of the nrDNA ITS sequence in plants (Baldwin, 1992), it has been extensively used to distinguish even very closely related species (Chen et al., 2010; Yao et al., 2010). Moreover, during the last two decades, the nrDNA ITS sequence has gained much attention as smartest gene available for the molecular signature of a taxon (Ali et al., 2013).

The present study is the first report of inferring the nrDNA ITS based molecular genotyping of the E. scordifolia. Since, the majority of the species of the genus Euphorbia have to be sequenced; the present study will nevertheless help in DNA barcoding / molecular identification of $E$. 
scordifolia as well as it will also participate in addressing the complete phylogeny of the genus Euphorbia. The DNA barcodes show promise in providing a practical, standardized, species-level identification tool that can be used for biodiversity assessment, life history, ecological studies and forensic analysis (Szabó et al., 2005; Mansour et al., 2009; Gyulai et al., 2012; Ali et al., 2014, 2015). Hence, the nrDNA ITS sequence of E. scordifolia will be of immense importance in barcoding of the genus Euphorbia in particular, and in the analysis of plant biodiversity of Saudi Arabia in general.

\section{Acknowledgement}

The authors would like to extend their sincere appreciation to the Deanship of Scientific Research at King Saud University for funding this research through the Research Group Project No. RGP-VPP-195.

\section{References}

Abedin, S., Mossa, J.S., Al-Said, M.S. and Al-Yahya, M.A. 2001. Euphorbiaceae. In: Chaudhary, S. (Ed.), Flora of Saudi Arabia, Ministry of Agriculture and Water, National Herbarium, National Agriculture and Water Research Center, Riyadh, Saudi Arabia, II(1): 291-395.

Ali, M.A., Al-Hemaid, F.M.A., Choudhary, R.K., Lee, J., Kim, S.Y. and Rub, M.A. 2013. Status of Reseda pentagyna Abdallah \& A.G. Miller (Resedaceae) inferred from analysis of combined nuclear ribosomal and chloroplast sequence data. Bangladesh J. Plant Taxon. 20(2): 233-238.

Ali, M.A., Gyulai, G., Norbert, H., Balázs, K., Al-Hemaid, F.M.A., Pandey, A.K. and Lee, J. 2014. The changing epitome of species identification - DNA barcoding. Saudi J. Biol. Sci. 21(3): 204-231.

Ali, M.A., Gyulai, G. and Al-Hemaid, F. 2015. Plant DNA Barcoding and Phylogenetics. LAP Lambert Academic Publishing, Germany, pp. 1-298.

Altschul, S.F., Gish, W., Miller, W., Myers, E.W. and Lipman, D.J. 1990. Basic local alignment search tool. J. Mol. Biol. 215: 403-410.

Baldwin, B.G. 1992. Phylogenetic utility of the internal transcribed spacers of nuclear ribosomal DNA in plants: an example from the Compositae. Mol. Phylogenet. Evol. 1: 3-16.

Baldwin, B.G., Sanderson, M.J., Porter, J.M., Wojciechowski, M.F., Campbell, C.S. and Donoghue, M.J. 1995. The ITS region of nuclear ribosomal DNA: a valuable source of evidence on angiosperm phylogeny. Ann. Miss. Bot. Gard. 82: 247-277.

Barres, L., Vilatersana, R., Molero, J., Susanna, A. and Galbany-Casals, M. 2011. Molecular phylogeny of Euphorbia subg. Esula sect. Aphyllis (Euphorbiaceae) inferred from nrDNA and cpDNA markers with biogeographic insights. Taxon 60(3): 705-720.

Benson, G. 1999. Tardem repeats finder: a program to analyze DNA sequence. Nucleic Acids Res. 27: 573-580.

Bruyns, P.V., Mapaya, R.J. and Hedderson, T. 2006. A new subgeneric classification of Euphorbia (Euphorbiaceae) based on ITS and psbA-trnH sequence data. Taxon 55: 397-420.

Buckler, E.S. and Holtsford, T.P. 1996a. Zea ribosomal repeat evolution and mutation patterns. Mol. Biol. Evol. 13: 623-632.

Buckler, E.S. and Holtsford, T.P. 1996b. Zea systematics: ribosomal ITS evidence. Mol. Biol. Evol. 13: 612-622.

Chen, S., Yao, H., Han, J., Liu, C., Song, J., Shi, L., Zhu, Y., Ma, X., Gao, T., Pang, X., Luo, K., Li, Y., Li, X., Jia, X., Lin, Y. and Leon, C. 2010. Validation of the ITS2 region as a novel DNA barcode for identifying medicinal plant species. PLoS ONE 5(1): e8613.

Frodin, D. 2004. History and concepts of big plant genera. Taxon 53: 753-776.

Gyulai, G., Horváth, L., Lágler, R. and Holly, L. 2012. The Hungarian gene bank collections of common millet (Panicum miliaceum) and the application for conservation genetics. European J. Plant Sci. Biotech. 6(SI2): 69-102.

Hall, T.A. 1999. BioEdit: a user-friendly biological sequence alignment editor and analysis program for Windows 95/98/ NT. Nuc. Acids. Sym. Ser. 41: 95-98. 
Mansour, A., Ismail, H.M., Ramadan, M.F. and Gyulai, G. 2009. Comparative genotypic and phenotypic analysis of tomato (Lycopersicon esculentum) cultivars grown under two different seasons in Egypt. African J. Plant Sci. Biotechnol. 3(1): 73-79.

Park, K.-R. and Jansen, R.K. 2007. A phylogeny of Euphorbieae subtribe Euphorbiinae (Euphorbiaceae) based on molecular data. J. Plant Biol. 50: 644-649.

Riina, R., Peirson, J.A., Geltman, D.V., Molero, J., Frajman, B., Pahlevani, A., Barres, L., Morawetz, J.J., Salmaki, Y., Zarre, S., Kryukov, A., Bruyns, P.V. and Berry, P.E. 2013. A worldwide molecular phylogeny and classification of the leafy spurges, Euphorbia subgenus Esula (Euphorbiaceae). Taxon 62(2): 316-342.

Rose, P.P. and Korber, B.T. 2000. Detecting hypermutations in viral sequences with an emphasis on G A hypermutation. Bioinformatics 16: 400-401.

Szabó, Z., Gyulai, G., Humphreys, M., Horváth, L., Bittsánszky, A., Lágler, R. and Heszky, L. 2005. Genetic variation of melon (C. melo) compared to an extinct landrace from the middle ages (Hungary) I. rDNA, SSR and SNP analysis of 47 cultivars. Euphytica 146: 87-94.

Steinmann, V.W. and Porter, J.M. 2002. Phylogenetic relationships in Euphorbieae (Euphorbiaceae) based on ITS and $n d h \mathrm{~F}$ sequence data. Ann. Miss. Bot. Gard. 89: 453-490.

Tamura, K., Peterson, D., Peterson, N., Stecher, G., Nei, M. and Kumar, S. 2011. MEGA5: molecular evolutionary genetics analysis using maximum likelihood, evolutionary distance, and maximum parsimony methods. Mol. Biol. Evol. 28(10): 2731-2739.

Tautz, D., Arctander, P., Minelli, A., Thomas, R.H. and Vogler, A.P. 2003. A plea for DNA taxonomy. Trends Ecol. Evol. 18(2): 70-74.

Thompson, J.D., Gibson, T.J., Plewniak, F., Jeanmougin, F. and Higgins, D.G. 1997. The Clustal X windows interface: flexible strategies for multiple sequence alignment aided by quality analysis tools. Nucleic Acids Res. 24: 4876-4882.

White, T.J., Bruns, T., Lee, S. and Taylor, J. 1990. Amplification and direct sequencing of fungal ribosomal RNA genes for phylogenetics. In: Innis, M.A., Gelfand, D.H., Sninksky, J.J. and White, T.J. (Eds), PCR Protocols: A Guide to Method and Amplifications. Academic Press, San Diego, pp. 315-322.

Yao, H., Song, J., Liu, C., Luo, K., Han, J., Li, Y., Pang, X., Xu, H., Zhu, Y., Xiao, P. and Chen, S. 2010. Use of ITS2 region as the universal DNA barcode for plants and animals. PLoS ONE 5(10): e13102.

Zimmermann, N.F.A., Ritz, C.M. and Hellwig, F.H. 2010. Further support for the phylogenetic relationships within Euphorbia L. (Euphorbiaceae) from nrITS and $t r n$ L-trnF IGS sequence data. Plant Syst. Evol. 286: 39-58.

(Manuscript received on 11 September 2015; revised on 22 October 2015) 